Volume 8, Nomor 2, 2020, 341-358

\title{
Implementasi Blended Learning Berbasis Guided Inquiry untuk Meningkatkan Communication Skill dan Collaboration Skill Mahasiswa di Era Industri 4.0
}

\author{
Pamungkas Stiya Mulyani \\ Universitas Sains Al-qur'an, Wonosobo, Indonesia \\ pamungkasstiyamulyani@gmail.com \\ Salis Irvan Fuadi \\ Universitas Sains Al-qur'an, Wonosobo, Indonesia \\ irvan@unsiq.ac.id
}

\begin{abstract}
Abstrak
Tujuan penelitian ini adalah mengetahui dampak penerapan Blended Learning berbasis Guided Inquiry dalam usaha meningkatkan Communication Skill Dan Collaboration Skill Mahasiswa untuk menjawab tantangan dan tuntutan Era Industri 4.0. Tujuan jangka panjang dari penelitian ini adalah sebuah informasi dan rekomendasi penyempurnaan blended learning berbasis guided inquiry untuk meningkatkan skill yang dibutuhkan mahasiswa dalam menjawab tantangan era industri 4.0. Penelitian ini merupakan penelitian tindakan kelas, mengadopsi model yang diintrodusir oleh McKernan. Penelitian menggunakan penggabungan metode kuantitatif dan kualitatif. Hasil penelitian menunjukan adanya peningkatan Communication Skill Dan Collaboration Skill Mahasiswa sebesar 0,48\% sebagai bekal mereka untuk menjawab tantangan di Era Industri 4.0.
\end{abstract}

Kata Kunci: Blended Learning, Guided Inquiry, Communication Skill, Collaboration Skill, Era Industri 4.0 


\begin{abstract}
The purpose of this study was to determine the impact of implementing Guided Inquiry-based Blended Learning in an effort to improve Student Communication Skills and Collaboration Skills to answer the challenges and demands of the Industrial Era 4.0. The long-term objective of this study is to provide information and recommendations for improving guided inquiry-based blended learning to improve the skills students need in responding to the challenges of the industrial era 4.0. This research is a classroom action research, adopting the model introduced by McKernan. This research uses a combination of quantitative and qualitative methods. The results showed an increase in Student Communication Skills and Collaboration Skills by $0.48 \%$ as their provision to answer challenges in the Industrial Era 4.0.
\end{abstract}

Keywords: Blended Learning, Guided Inquiry, Communication Skill, Collaboration Skill, Industrial Era 4.0

\title{
A. Pendahuluan
}

Revolusi Industri 4.0 telah mengubah hidup dan kerja manusia secara fundamental, dimana ruang lingkup dan kompleksitas yang lebih luas dan kemajuan teknologi baru yang mengintegrasikan dunia fisik, digital dan biologis telah mempengaruhi semua disiplin ilmu, ekonomi, industri dan pemerintah (Schwab, 2017). Paulina (2018) yang mengutip pendapat Zimerman, bahwa setidaknya ada 75\% pekerjaan yang dilakukan pada era Revolusi Industri 4.0 melibatkan sains, teknologi, teknik dan matematik, internet of things, dan pembelajaran sepanjang hayat. Muatan pembelajaran abad 21 harus selalu menyesuaikan dengan perubahan termasuk di era industri 4.0. Muatan pembelajaran diharapkan mampu memenuhi keterampilan abad 21 adalah, 1) pembelajaran dan keterampilan inovasi meliputi penguasan pengetahuan dan keterampilan yang beraneka ragam, pembelajaran dan inovasi, berpikir kritis dan penyelesaian masalah, komunikasi dan kolaborasi, dan kreatifitas dan inovasi, 2) keterampilan literasi digital meliputi literasi informasi, literasi media, dan literasi ICT, 3) karir dan kecakapan hidup meliputi fleksibilitas dan adaptabilitas, inisiatif, interaksi sosial dan budaya, produktifitas dan akuntabilitas, dan kepemimpinan dan tanggung jawab (Muhammad, 2018). Berdasar keterampilan abad 21 tersebut, peneliti melihat bahwa keterampilan 
komunikasi (communication skill) dan keterampilan bekerjasama (collaboration skill) adalah dua keterampilan yang paling dibutuhkan oleh mahasiswa pada saat proses kuliah. Hal ini dibuktikan dengan hasil survey National Association of Colleges and Employeds pada tahun 2002, dan diperkuat oleh Crawford et al (2011) yang menempatkan keterampilan berkomunikasi dan kerjasama pada posisi atas pada clusternya ini berdasar dari hasil The Research Team at Michigan State University, ini menunjuklan bahwa keterampilan berkomunikasi dan kerjasama merupakan keterampilan yang paling dibutuhkan oleh manusia untuk kemajuannya. Sedangkan ketrampilan berfikir kritis sendiri dan pemecahan masalah akan terbentuk dengan sendirinya oleh pembelajaran yang bersifat membangun (Kontruktivisme) (Banar, 2015).

Menjawab dari masalah-masalah tersebut, diperlukan suatu bentuk model perkuliahan yang tepat dan efisen untuk mengatasinya, yaitu dengan memadukan antara perkuliahan konvensional (tatap muka) dengan perkulihan online atau yang dikenal dengan Blended learning. Dwiyogo (2016) mendefinisikan blended learning mengacu pada belajar yang mengkombinasi atau mencampur antara pembelajaran tatap muka (face to face) dan pembelajaran berbasis komputer (online dan offline). Definisi tersebut mengandung makna bahwa Blended Learning menggambarkan sebuah kesempatan yang mengitegrasikan inovasi dan keuntungan teknologi pada pembelajaran online dengan interaksi dan partisipasi dari keuntungan pembelajaran tatap muka. Hasamah yang mengutip Semler menyatakan, blended learning adalah sebuah kemudahan pembelajaran yang menggabungkan berbagai cara penyampaian, model pengajaran, dan gaya pembelajaran, memperkenalkan berbagai pilihan media dialog antara fasilitator dengan orang yang mendapat pengajaran (Husamah, 2014 ) Blended learning tidak berarti menggantikan model belajar konvesional di dalam kelas, tetapi memperkuat model belajar tersebut melaluipengayaan content dan pengembangan teknologi pendidikan (Jusuf \& Heni, 2016). Adapun sintaks Blended learning sebagai berikut 1) seeking of information, pencarian informasi dari berbagai sumber informasi yang 
tersedia di TIK (online), buku, maupun penyampaian melalui face to face di kelas. 2) acquisition of information, menginterprestasi dan mengelaborasi informasi secara personal maupun komunal. 3) synthesizing of knowledge, merekonstruksi pengetahuan melalui proses asimilasi dan akomodasi bertolak dari hasil analisis, diskusi dan perumusan kesimpulan dari informasi yang diperoleh (Rusman, 2016).

Beberapa penelitian menunjukan peningkatan dari penggunaan Blended Learning untuk berbagai macam hasil kemampuan mahasiswa. Ayu (2013) telah membuktikan dalam penelitiannya di IKIP Mataram bahwa pembelajaran dengan menggunakan blended learning dapat meningkatkan hasil belajar mahasiswa termasuk peningkatan dalam ranah afektifnya. Muhammad, Erwin, \& Irvan (2017) membuktikan bahwa perkuliahan berbasis blended learning berdampak pada rencana tindak lanjut perkuliahan jika perkuliahan tersebut menggunakan strategi evaluasi yang tepat. Penggunaan Blended learning mampu memenuhi tuntutan revolosi Indutri 4.0 dimana perkuliahan dapat dilaksanakan sepanjang hayat, hal ini menjadikan waktu perkuliahan tidak hanya terbatas pada bobot SKS pada matakuliah saja dan pembelajaran ini merupakan penggunaan perkembangan teknologi yang tepat guna serta internet of things sehingga mahasiswa dapat mengeksplore pengetahuannya secara total. Dalam perkuliahan ini yang digunakan adalah media aplikasi Telegram. Aplikasi ini dipilih karena memiliki kelebihan daripada aplikasi lain, yaitu 1) mudah dalam pengoprasiannya, 2) dapat di buka melalui smart phone maupun komputer, 3) penyimpanan data dilakukan di dua tempat yaitu memory smart phone/komputer dan di telegramnya sendiri. Sehingga jika memori smartphone atau komputer terhapus data yang berupa gambar, file atau dokumen dapat di unduh kembali.

Guided inquiry sebagai dasar jalannya proses Blended learning, hal ini digunakan untuk memberikan stimulus pokok permasalahan kepada mahasiswa untuk di diskusikan serta memberikan arahan dan rambu rambu pembetulan oleh Dosen. Piaget mengemukakan bahwa model inquiry adalah model yang mempersiapkan pada situasi untuk melakukan eksperimen sendiri secara luas agar 
melihat apa yang terjadi, ingin mencari jawaban sendiri serta menghubungkan penemuan yang satu dengan penemuan yang lain, kemudian membandingkan apa yang ditemukan dengan yang ditemukan siswa lainnya (Andriani et al, 2011). Karakteristik utama dari guided inquiry adalah sebagai berikut: 1) mahasiswa belajar mulai dari melakukan observasi spesifik yang dapat mengarahkannya untuk membuat inferensi atau membuat generalisasi; 2) kegiatan belajar bertujuan untuk menfasilitasi mahasiswa dalam mempelajari atau menguatkan proses pengujian suatu kejadian atau objek dan kemudian menemukan generalisasi yang tepat dari observasi; 3) dosen mengontrol kekhususan pembelajaran yang berupa peristiwa, data, materi, objek dan bertindak sebagai pemimpin dalam kelas; 4) tiap-tiap mahasiswa diarahkan agar berusaha membangun pola-pola yang bermakna berdasar hasil observasinya sendiri serta hasil temuan teman-temannya dalam kelas; 5) kelas harus dikondisikan agar berfungsi sebagai laboraturium pembelajaran; 6) dosen harus berusaha memberi semangat agar mahasiswa berlatih mengkomunikasikan generalisasi yang telah dikembangkan melalui aktivitas presentasi dan mahasiswa lainnya mendapatkan manfaat (Jufri, 2013).

Pengembangan Framework pembelajaran di abad 21 yang menuntut mahasiswa untuk memiliki keterampilan, pengetahuan dan kemampuan dibidang teknologi, media dan informasi, keterampilan pembelajaran dan inovasi serta keterampilan hidup dan karir. Adapun penjelasan mengenai framework pembelajaran abad ke-21 diantaranya sebagai berikut: Kemampuan berkomunikasi dan bekerjasama (Communication and Collaboration Skills), mampu berkomunikasi dan berkolaborasi secara efektif dengan berbagai pihak. Literasi teknologi informasi dan komunikasi (Information and Communications Technology Literacy), mampu memanfaatkan teknologi informasi dan komunikasi untuk meningkatkan kinerja dan aktivitas sehari-hari, dan mampu memahami dan menggunakan berbagai media komunikasi untuk menyampaikan beragam gagasan dan melaksanakan aktivitas kolaborasi serta interaksi dengan beragam pihak (Maya, B \& C, Fadel, 2015). Communication Skill terdiri atas dua jenis yaitu secara 
Written dan Oral. Adapun indikator written communication skill adalah: menjelaskan arti bacaan, menemukan ide utama bacaan, membedakan dan menganalisis pesan media, menjelaskan suatu masalah dengan masuk akal dan memadai, menyampaikan ide/gagasan melalui tulisan, menafsirkan arti simbul, membuat dan membaca tabel, membuat dan membaca grafik, membuat dan membaca angka. Sedangkan untuk oral communication skill indikatornya adalah: menyampaikan ide secara lisan, mengungkapkan kembali hasil pembicaraan, mengidentifikasi suasana hati lawan bicara, mempengaruhi lawan bicara secara positif, memberikan presentasi sesuai dengan rencana kepada audiens (Widodo, 2014). Indikator dari collaboration skill adalah sebagai berikut: menggunakan kesepakatan, menghargai kontribusi, mengambil giliran dan berbagi tugas, merada dalam kelompok, merada dalam tugas, mendorong partisipasi, mengundang orang lain untuk berbicara, menyelesaikan tugas pada waktunya, menghormati perbedaan individu, menunjukkan penghargaan dan simpati, mengungkapkan ketidak setujuan dengan cara yang dapat diterima, mendengarkan dengan aktifmbertanya, membuat ringkasan, menafsirkan, mengatur dan mengorganisir, menerima tanggung jawab, mengurangi ketegangan (Widodo, 2014).

Penelitian menggunakan penggabungan metode kuantitatif dan kualitatif. Metode kuantitatif dilakukan dengan melakukan pengukuran menggunakan angket Skala Likert dengan 4 (Empat) Standar dan respondennya adalah Mahasiswa, selanjutnya dikonversikan kedalam bentuk data numerik untuk ditabulasikan. Metode kualitatif dengan menggunakan lembar pengamatan dan quisioner yang bertujuan untuk memperoleh informasi jalannya penerapan perlakuan oleh Dosen dan upaya mendapatkan informasi penyempurnaan penerapan model, serta mahasiswa selaku objek penelitian dan pihak yang merasakan dampaknya. Observasi secara langsung untuk mendapatkan data perkembangan Written Communication Skill Mahasiswa. dan instrument yang telah dilakukan validasi oleh tiga validator ekspert dan disesuaikan dengan informasi yang dibutuhkan sesuai dengan tahapan alur penelitian. 


\section{B. Pembahasan}

Penelitian ini dilaksanakan dalam dua kali siklus penelitian. Penelitian ini dilaksanan di Universitas sains Al-Qur'an pada prodi Pendidikan Guru Madrasah Ibtidaiyah semester IV pada tahun 2020. Pada tahap perencanaaan gambaran mekanisme penerapan blended learning berbasis guided inquiry untuk meningkatkan communication skill dan collaboration skill sebagai berikut: 1) Menyusun RPS mata kuliah media teknologi informasi dengan model pembelajarannya blended learning berbasis Guided Inquiry dan menambahkan group whatsapp sebagai mediannya. 2) Peneliti membuat group whatsapp yang beranggotakan mahasiswa yang mengambil mata kuliah media teknologi informasi serta membuat kelompok kelompok grub kecil didalamnya supaya untuk mempermudah pengawasan dan pengontrolan. 3) Pada pertemuan pertama peneliti menjelaskan apa saja yang akan kita pelajari dalam satu semester kedepan, produk seperti apa yang akan di hasilkan sebagai hasil dari perkuliahan, membagi kelas dalam beberapa kelompok beserta tugas yang harus di kerjakannya, serta bagaimana fungsi group whatsapp selama proses perkuliahan termasuk dalam proses ini adalah berdiskusi mengenai problem-problem perkuliahan. Kegiatan ini dilakukan sebelum protocol kesehatan pandemi covid diterapkan namun dalam perjalannyannya protikol kesehatan tersebut di terapkan sehingga perlu adanya aplikasi tambahan yaitu google class room sebagai pengganti kegiatan tatap muka secara virtual yang dikarenakan pandemi covid yang mengharuskan menggunakan protokoler kesehatan. 5) Mahasiswa diminta untuk mempersiapkan bahan atau referensi perkuliahan sesuai tema yang didapatkan sebelumnya dan mendiskusikannya dalam group whatsapp dan di presentasikan menggunakan google class room. 6) Setiap mahasiswa yang berinisiasi untuk mendiskuskan apa yang telah dilakukan diberi poin tersendiri. Dan peneliti melihat perkembangan kemampuan komunikasi serta kerjasama tiap mahasiswa. 7) Peneliti mengevaluasi perkembangan kemampuan komunikasi dan kerjasama tiap mahasiswa memalui group whatsapp dan google class room setiap waktu. Serta mencari solusi guna 
menyelesaikan permasalahan tersebut. 8) Merefleksikan proses yang telah dilakukan selama dua siklus dan membuat keputusan mengenai perubahan apa yang diperlukan dalam penggunaan group whatsapp.

Mekanisme tersebut merupakan hasil penyempurnaan yang terakir setelah dilakukan konsultasi dengan teman sejawat dan pakar, dimana yang terpenting dalam mekanisme pembelajaran ini adalah mahasiswa tertangani dengan baik dan terlayani dengan baik, bermakna dan dapat di aplikasikan kedalam kehidupan mereka. Serta mahasiwa setelah melakukan perkuliahan memiliki keterampilan dan karakter yang terbentuk. Namun untuk penyesuaian dengan protokoler kesehatan covid 19 ini di harap mahasiswa juga mampu cepat menyesuaikannya. Harapannya dengan memanfaatkan perkembangan teknologi perkuliahan pada situasi pandemi ini bukan sebuah halangan, namum menjadi familier dan tidak gagap teknologi, mahasiswa menjadi mahir dalam mengoperasikan, terlebih sesuai dengan tujuan dari matakulaih ini. Bentuk SAP dan RPS terdapat materi yang akan dibahas dan pelajari selama satu semester kedepan, jadwal pertemuan dan referensi utama apa yang digunakan, tujuan pembelajaran, indikator yang akan di capai, karakter yang akan di munculkan atau ditingkatkan, metode dan strategi pembelajaran, serta bentuk dan cara penilaian yang akan dilaksanakan. Selain itu sebelum digunakan SAP dan RPS ini di konusltasikan dan di sahkan oleh Ka Prodi.

Tahap kedua adalah implementasi, berdasar dari quisioner yang diberikan kepada dosen pengampu Mata kuliah, diperoleh informasi bahwa dosen pengampu dalam melaksanakan pembelajarannya sudah sesuai dengan tujuan yang akan dicapai dalam RPS dan SAP baik urutan kegiatan, dan jadwalnya serta materi yang disampaikannya, serta sudah memberikan motivasi kepada mahasiswa, namun menurut pandangan observer dosen kurang dalam menerima respon mahasiswa, dosen masih merasa canggung dalam memberikan penguatan dan menanggapi tingkah laku dan mengondisikan mahasiswa, dosen lebih cenderung melakukan pembiaran dan kurangnya pembimbingan serta pemantauan terhadap grup mahasiswa maupun saat diskusi melalui google class room. hal ini karenakan 
dosen juga perlu dalam penyesuaian mekanisme pembelajaran baru. Selain itu Dosen kurang memastikan kemantapan mahasiswa akan produk teknologi informasi yang akan dibuatnya, Dosen juga kurang memastikan mahasiswa dapat mempresentasikan manfaat dan kelebihannnya. Sehingga dalam ber presentasi mahasiswa masih bingung mengenai prodaknya dan hal apa saja yang harus di presentasikan mengenai produknya. Dalam pertemuan tatap muka pertama kali mahasiswa dan dosen belum berlakunya protokol kesehatan pandemi covid 19. Dosen dan mahasiswa selanjutnya dituntut untuk dapat menyesuiakan diri dengan kebiasaan pembelajaran tatap muka secara virtual menggunakan aplikasi google class room dan zoom.

Kendala-kendala yang dialami oleh dosen pengampu pada pelaksanaan pembelajaran blended learning pada siklus pertama adalah antara dosen dan mahasiswa masih kurang familier dalam melaksanakan pembelajaran, terlebih pembelajaran tatap mukanya harus di bantu dengan aplikasi google class room yang dikarenakan situasi pandemi, kurang aktif dan meresponnya mahasiswa dan dosen, kurangya antusiasnya mahasiswa dalam memberikan tanggapan pada saat diskusi, baik saat dalam grub whatsapp maupun saat kelompok lain presentasi pada aplikasi google class room, mahasiswa cenderung hanya menyimak saja. Dosen juga kurang melakukan pengawasan dan kontrol sehingga mengalami kesulitan dalam mengendalikan kelas. Jaringan internet kurang bagus sehingga dalam menggunakan aplikasi google class room sebagai pengganti pertemuan tatap muka kurang berjalan denagn baik, terlebih pada mahasiswa yang berada jauh dari pusat kota atau tower pemancar provider. Dalam pencarian referensai mahasiswa lebih cenderung asal ambil dan mencopy saja, dalam berdiskusi mahasiswa masih menyampaikan argumentasinya dengan bercanda, dan dengan bahasa yang masih berbelit belit. Pembahasan pada fokus materi kurang, dan kurang menghargai kelompok yang sedang presentasi. Hal ini menjadikan adanya perbaikan untuk pembelajaran pada siklus yang ke dua. 
Berdasar informasi dari kemampuan komunkasi tertulis (written communication) mahasiswa pada siklus pertama in, dapat diambil kesimpulan bahwa mahasiswa pada dasarnya memiliki kemampuan komunikasi tertulis yang diperoleh berdasar pengalaman atau ajaran hidup yang mereka alami sebelum mengikuti mata kuliah ini, hal ini menjadi dasar komunikasi tertulis mahasiswa. Namun masih banyak pola komunikasi tertulis mahasiswa yang hanya berdasar pada pandangan dan asumsi pribadi mereka dan hanya bersifat untuk dirinya sendiri, mahasiswa belum dapat memberikan komunikasi yang lebih detail, kritis dengan sudut pandang dari bergaia aspek dan lebih komunikatif, mahasiswa masih menggunakan bahasa yang sukar dipahami. Hal ini menjadi perhatian dosen dan peneliti untuk mencari solusi supaya mahasiswa berlatih untuk dapat lebih dapat berkomunikasi secara tertulis ini.

Keterampilan komunikasi lisan dan kerjasama mahasiswa dapat diamati dari bagaimana dia bersosialisasi dengan sesama mahasiswa dan orang lain, dalam hal ini peneliti menggunakan angket penilaian teman sejawat. Dari hasil angket diperoleh informasi bahwa kemampuan keterampilan komunikasi lisan dan kerjasama (Oral Communication And Collaboration) mahasiswa dapat dilihat pada gambar 1.

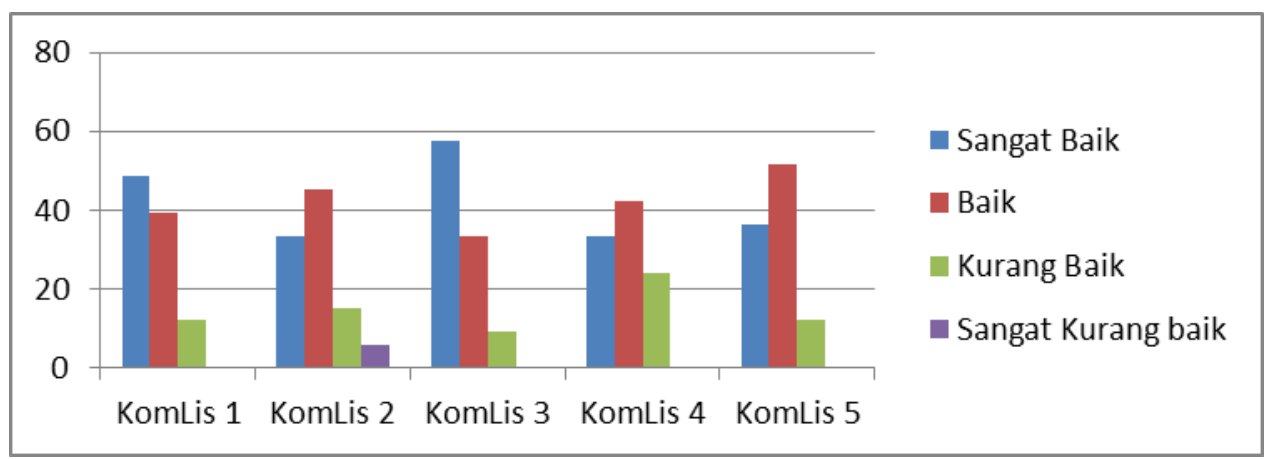




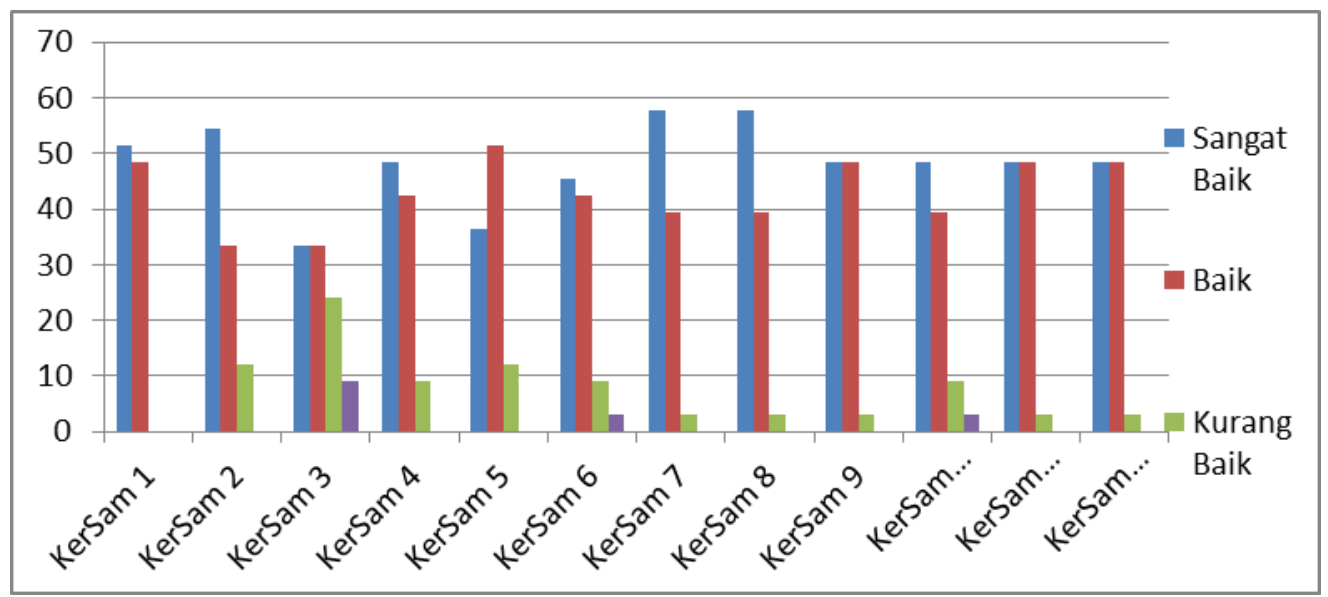

Sumber: Data Penelitian.

Gambar 1. Grafik Kemampuan Komunikasi Lisan dan Kerjasama Siklus Pertama

Berdasarkan informasi global yang diperoleh dari angket komunikasi lisan dan kerjasama diperoleh mahaisiswa pada dasarnya sudah memiliki kemampuan komunikasi lisan dan kerjasama yang baik dan sangat baik, namun masih ada beberapa mahasiswa yang kurang baik atau bahkan sangat tidak baik. Hal ini terlihat pada tanggung jawab mahasiswa yang masih ada yang menyepelekan dan tidak bertanggung jawab, kedatangan yang sering terlambat dan tidak menghargai waktu. Masih adanya mahasiswa yang kurang menghargai pendapat orang lain serta memaksakan diri untuk menggunakan pendapatnya. Serta masih ada mahasiswa yang cuma ikut numpang nama dalam kelompoknya. Itu semua menjadi tugas dosen untuk lebih memberikan bimbingan, pengawasan dan pemantauan kepada mahasiswa baik melalui grup whatsapp maupun google class room. Terlebih tuntutan dan tantangan era revolusi industri 4.0 dimana mahasiswa di tuntun bergerak cepat, disiplin serta mampu menghasilkan karakter yang baik supaya bisa bersaing dengan dunia luar.

Tahap yang selanjutnya adalah evaluasi, berdasar dari serangkaian tahap dari awal hingga implementasi pada siklus pertama ini diperoleh informasi bahwa dosen masih bayak menemukan banyak kendala baik dari dosen pengampu mata kuliah maupun dari mahasiswa, dosen masih belum dapat menyesuaikan dengan model daring karena pandemi corona ini, dosen kurang maksimal dalam 
memberikan bimbingan, mendampingi serta memantau mahasiswa suapa diskusi sesuai jalur. Dari dosen masih sering melakukan pembiaran dan tidak memberikan solusi. Dari mahasiswa masih banyak mahasiswa yang tak acuh pada diskusi, diam dan hanya sebagai penonton saja. Bahkan ada yang tidak memperdulikan apa yang sedang dibicarakan. Rencana langkah yang akan dilakukan oleh peneliti dan dosen adalah melakukan diskusi dengan berkonsultasi dengan pakar untuk dapat memberikan solusi yang terbaik. Dan dapat dilaksanakan oleh dosen dalam melaksanakan pembelajaran. Respon mahasiswa semakin baik dan mahasiswa mudah diajak kerjasama dan dibimbing sehingga mudah untuk mengondisikan mahasiswa untuk menjadikan diskusi yang sesuai dengan harapan. Serta mengulang materi yang dirasa mahasiswa belum dapat memahami sepenuhnya. Tahap yang terakir pada siklus pertama adalah kesimpulan skema penerapan tindakan kelas belum dapat berjalan maksimal sesuai harapan, masih banyak pembenahan dan perbaikan yang terjadi. ditambah pada siklus pertama terjadi transisi dari pembelajaran tatap muka langsung menjadi pembelajaran secara daring sebagai pengganti tatap muka, hal ini juga memperlukan penyesuaian. Belum lagi masalah alat seperti smart phone mahasiswa yang harus dapat menyesuaikan dengan kebutuhan guna lancarnya pembelajaran serta peran provider dan adanya paket data yang dimiliki oleh mahasiswa.

Siklus kedua Dosen telah melaksanakan kewajibannya dengan baik, mulai dari membangun komunikasi yang komunikatif dengan mahasiswa, tanggap dan peka dengan permasalahan yang ada pada mahasiswa, intens dalam memantau, membimbing, dan mendampingi mahasiswa para proses pembelajaran baik secara daring maupun online grup merespon pertanyaan dari mahasiswa. Dan segera memberikan tanggapan dengan pertanyaan pertanyaan yang membimbing mahasiswa untuk menemukan sendiri pengetahuannya, memberikan pertanyaan kepada mahasiswa guna mengarahkan ke arah tujuan diskusi. Serta memberikan bantuan quota bagi mahasiswa yang mengalami kesulitan dalam memberi quota internet. Serta membantu mencarikan solusi kepada mahasiswa yang mengalami 
kesulitan dalam mengikuti grup whatsapp maupun google class room karna terkendala perangkat.

Output berupa perkembangan kemampuan written communication skill dari proses tindakan pada siklus kedua ini terdapat lima indikator yang diamati oleh peneliti, dan masing masing indikator telah diberi kemudahan penilainnya dengan rubrik penilaiannya, mengingat pada instrumen ini menggunakan jawaban panjang dalam mahasiswa menjawabnya sehingga sangat dibutuhkan rubrik penilaiannya. Generalisasi dari lembar quisioner keterampilan komunikasi tertulis yang diberikan kepada mahasiswa pada siklus kedua ini mendapatkan informasi secara global bahwa siklus kedua ini mahasiswa sudah mengalami perubahan ke arah yang lebih baik daripada saat siklus pertama. Walaupun belum semua mahasiswa telah mengalami peningkatan dalam hal kemampuan keterampilan komunikasi lisannya. Ini menjadi informasi lanjutan untuk dosen atau peneliti lain sebagai bahan kajian risetnya.

Kemampuan yang diamanti berikutnya adalah kemampuan komunikasi tertulis dan kerjasama (oral communication and collaboration). Peneliti menggunakan angket penilaian teman sejawat sebagai alat untuk mendapatkan informasi dari mahasiswa dengan lima indikator keterampilan komunikasi lisan dan dua belas keterampilan kerjasama adapun hasil dari siklus kedua daapt dilihat pada gambar 2.

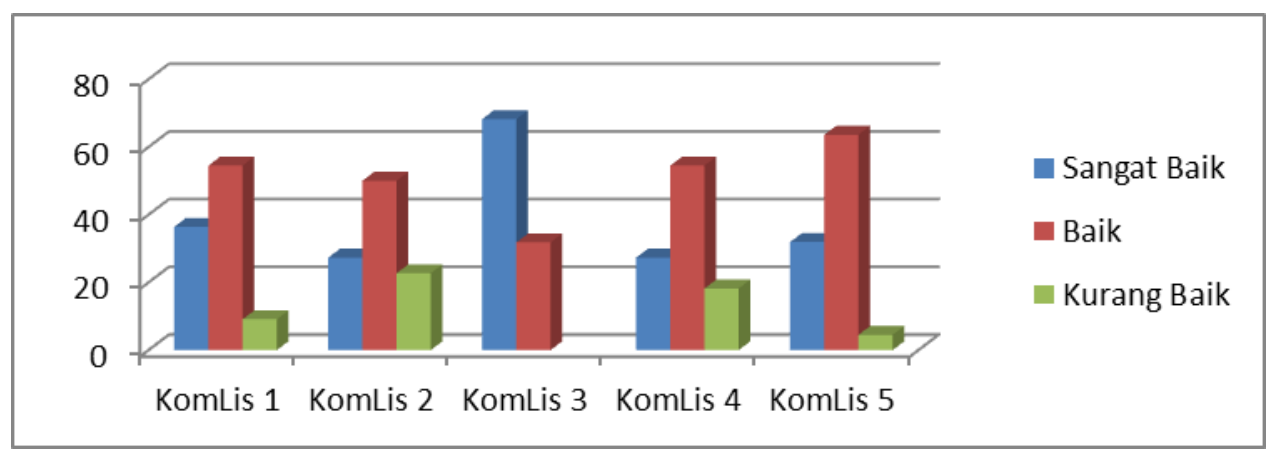




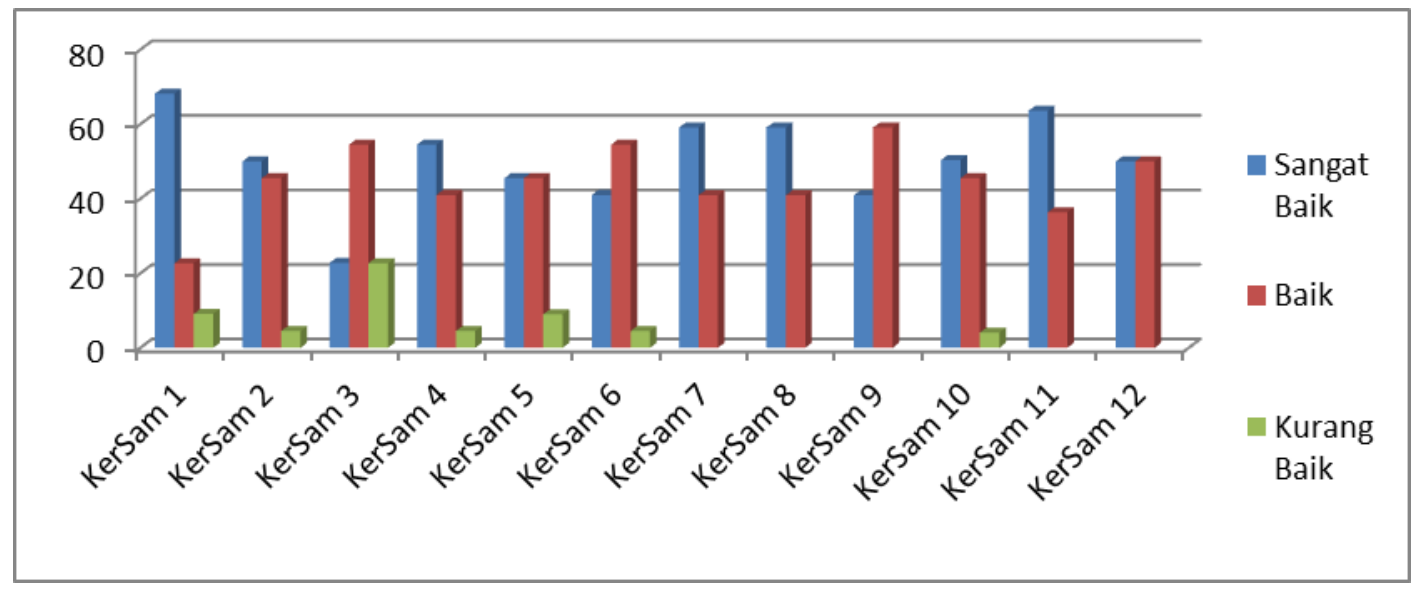

Gambar 2. Grafik Kemampuan Komunikasi Lisan dan Kerjasama Siklus Kedua

Berdasarkan hasil analisis pada siklus pertama dan kedua, diperoleh informasi adanya penurunan prosentase katagori sangat baik di sebagian besar indikator, dan peningkatan kategori baik di sebagian indikator. Setelah dilakukan observasi dan penelurusuran sebab oleh peneliti diperoleh informasi bahwa terjadinya hal tersebut dikarenakan pertama adalah faktor emosi mahasiswa, dimana pada awal penerapan emosi mahasiswa cenderung antusias jadi semangat dalam melaksanakannya sehingga dalam prakteknya mahasiswa menjadi sangat baik, dan pada perlakuan siklus kedua mahasiswa lebih menjadi berkurang antusiasnya sehingga lebih banyak kategori baiknya. Dan adanya pengurangan jumlah prosentase mahasiswa dengan kategori kurang baik atau sangat kurang baik menjadi baik hal ini terlihat dengan prosentase indikator tersebut mengalami penurunan.

Selain itu faktor karakter yang sudah terbentuk sebelumnya dari mahasiswa (karakter bawaan) juga mempengaruhi hasil dari penerapan penelitian tindakan kelas ini, ini menjadi modal awal bagi dosen untuk keberhasilan penelitian tindakan kelas ini. Namun yang digaris bawahi adalah adanya mahasiswa pengobatan bagi mahasiswa mahasiswa yang pada awalnya berkatagori kurang baik atau sangat kurang baik yang dikarenakan kurang merespon, atau karena karakter bawaanya adalah pemalas dan acuh. Hal ini terlihat dengan berkurangnya prosentase pada dua 
karakter tersebut dan karena adanya pengobatan melalui inquiry terbimbing mahasiswa yang tadinya baik juga ada yang menjadi katagori sangat baik. Hal ini membuktikan bahwa wujud akhir pembelajaran inquiry adalah adanya berubahan perilaku ke arah yang lebih baik (Wardoyo, 2013).

Tahapan pembelajaran inquiry yang terakir adalah bahwa pembelajaran disimpulkan dengan produk akhir atau hasil yang nampak, dalam pembelajaran yang diterapkan dosen memberikan tugas proyek kepada mahasiswa berupa produk akhir pembelajaran, pada siklus pertama adalah mereka diminta untuk membuta penjelasan mengenai produk produk teknologi informasi sementara pada siklus kedua adalah mereka diminta untuk membuat produk informasi teknologi . Dan yang tidak kalah pentingnya adalah produk akhir berupa adanya perubahan kearah yang lebih baik dari keterampilan mereka dalam peneltian ini adalah keterampilan komunikasi (communication skill) dan keterampilan kerjasama (collaboration skill) dimana dengan adanya peningkatan keterampilan akan menjadikan terbentuknya karakter mahasiswa yang lebih baik guna mempersipkan untuk dapat mengikuti alur dan bersaing sesuai tuntutan jaman revolusi industri 4.0 ini.

Revolusi industri saat ini memasuki fase keempat. Perkembangan ilmu pengetahuan dan teknologi yang sangat pesat memberikan dampak yang besar terhadap kehidupan manusia. Banyak kemudahan dan inovasi yang diperoleh dengan adanya dukungan teknologi digital. Layanan menjadi lebih cepat dan efisien serta memiliki jangkauan koneksi yang lebih luas dengan sistem online. Hidup menjadi lebih mudah dan murah. Penggunaan Aplikasi Whatsapp pada pembelajaran ini merupakan penggunaan dari manfaat teknologi era Industri 4.0 dalam memperluas konektifitas pembelajaran online, di lain pihak Framework pembelajaran di abad 21 yang menuntut mahasiswa untuk memiliki keterampilan, berkomunikasi dan bekerjasama (Communication and Collaboration Skills) dapat diasah dan ditingkatkan melalui pembelajaran ini. 


\section{Simpulan}

Pembelajaran yang sangat tepat di era revolusi ini adalah pembelajaran yang menggabungkan antara sains, teknologi, teknik dan matematik, internet of things, dan pembelajaran sepanjang hayat dan blended learning yang di gabungkan dengan inquiry terbimbing adalah solusinya. Dimana blended learning adalah pembelajaran yang menjebatani adanya komunikasi antara dosen dan mahasiswa tanpa terkendala oleh waktu dan tempat. Sementara inquiry terbimbing merupakan pembelajaran yang dilakukan secara terus menerus dimana dosen selalu membimbing dan mengawal mahasiswa dalam menemukan pengetahuannya. Inquiry terbimbing juga merupakan pembelajaran yang sifatnya mandiri, sehingga cenderung lebih dapat membuat mahasiswa lebih aktif, menemukan sendiri solusinya sehingga dalam prosesnya dapat membentuk dan meningkatkan kemampuan komunikasinya dan kerjasamanya. Disisi lain inquiry mengharuskan adanya produk akhir yang menjadi tujuan pembelajaran. Disini produk berupa hasil keterampilan mahasiswa dan juga pengembangan keterampilan mahasiswa.

\section{Daftar Pustaka}

Andriani, N. I. Husaini,\& L. Nurliyah. 2011. Efektifitas Penerapan Pembelajaran Inkuiri Terbimbing (Guided Inquiry) pada Mata Pelajaran Fisika Pokok Bahasan Cahayadi Kelas VIII SMP Negeri 2 Muara Padang.Prosiding Simposium Nasional Inovasi Pembelajaran \& Sains 22-23 Juni, Bandung.

Ayu. C.D. 2013. Pengaruh Blended Learning Dalam Pembelajaran Berbasis Masalah (PBL) Terhadap Hasil Belajar Mahasiswa IKIP Mataram Pada Materi Pencemaran Lingkungan, Jurnal Prisma, Vol.1, No.1

Banar, D.R. 2015. Pengembangan Model Pembelajaran Inquiry Terbimbing Berbasis Pandangan Ki Hadjar Dewantara Untuk Menumbuhkan Kompetensi Unggul Di SMP. Jurnal PPKM. Vol 03, No.01. Hal. 30-38

Crawford, P. S. Lang,R. Dalton, W. Fink,\&L. Fielitz. 2011. Comparative Analysis of Soft Skills: What is important for New graduates. What soft skill are employers looking for in new graduates. Michigan: Michigan State University. 
Fatmawati, N., Setyowati, D. L., \& Utomo, C. B. 2018. "Outdoor Study Activity by Utilizing Wonosoco Tourism Village as A Learning Resource of Social Studies". Journal of Educational Social Studies, 7 (1): 88-98.

Husamah. 2014. Pembelajaran Bauran (Blended Learning). Jakarta : Prestasi Pustaka Pers.

Jufri, W. 2013.Belajar \& Pembelajaran Sains. Bandung: Pustaka Reka Cipta

Jusuf \& Heni. 2016. Pengembangan Blended Learning Untuk Memotivasi Peserta Didik Dalam Memahami Materi Ajar. Jurnal Ilmu Teknologi Informasi Terapan, Vol. 3 No. 1 Hal 28-36.

Kusamah \& Dwitagama. 2009. Mengenal Penelitian Tindakan Kelas. Jakarta: PT Indeks

Maya, B \& C, Fadel. 2015. Skills for the 21st Century: What Should Students Learn?., Massachusetts: Center for Curriculum Redesign Boston

Muhammad, Erwin, \& Irvan. 2017. Strategi Evaluasi Program Perkuliahan Biologi Berbasis Blended Learning, Jurnal Bioedukatika, Vol. 5, No. 2

Muhammad, Y. 2018. Era Industri 4.0: Tantangan Dan Peluang Perkembangan Pendidikan Kejuruan Indonesia. Makalah disampakan pada Sidang Terbuka Luar Biasa Senat Universitas Negeri Makassar Tanggal 14 Maret 2018

Paulina, P. 2018. Mempersiapkan SDM Indonesia di Era Industri 4.0. Makalah dipresentasikan pada Seminar Era Industri 4.0, Kemenristek Dikti Jakarta

Penulisan Dwiyogo. 2016. Pembelajaran Berbasis Learning (Model Pembelajaran). Malang: Wineka Media..

Rusman. 2016. Model-Model Pembelajaran Mengembangkan Profesionalisme Guru. Jakarta: Rajawali

Schwab, K. (2017). The fourth industrial revolution. Crown Business Press.

Slamet. R, 2018. Revolusi Industri 4.0: Peluang dan Tantangan Bagi Alumi Universitas Terbuka. Disampaikan dalam Pidato Akademik Wisuda. Unsoed

Wardoyo, S. M. 2013. Pembelajaran Berbasis Riset. Jakarta: Akademia Permata

Widodo, W. 2014. Tinjauan tentang Keterampilan Generik. Tersedia di vahonov.files.wordpress.com/.../tinjauan-tentang-keterampilan-generik.pdf [diakses 20/07/2019]. 
Pamungkas Stiya Mulyani dan Salis Irvan Fuadi 